\title{
Chloroplast genomes of five Oedogonium species: genome structure, phylogenetic analysis and adaptive evolution
}

\author{
Qian Xiong ${ }^{1,2}$, Yuxin $\mathrm{Hu}^{3}$, Wenqi $\mathrm{Lv}^{1,2}$, Qinghua Wang ${ }^{4}$, Guoxiang Liu ${ }^{1 *}$ and Zhengyu $\mathrm{Hu}^{1,5}$
}

\begin{abstract}
Background: The order Oedogoniales within the single family Oedogoniaceae comprised of three genera, Oedogonium, Oedocladium, and Bulbochaete based on traditional morphological criteria. While several molecular phylogenetic studies have suggested that both Oedogonium and Oedocladium may not be monophyletic, broader taxon sampling and large amounts of molecular data acquisition could help to resolve the phylogeny and evolutionary problems of this order. This study determined five chloroplast (cp) genomes of Oedogonium species and aimed to provide further information on cp genome for a better understanding of the phylogenetic and evolutionary relationships of the order Oedogoniales.
\end{abstract}

Results: The five Oedogonium cp genomes showed typical quadripartite and circular structures, and were relatively conserved in their structure, gene synteny, and inverted repeats boundaries in general, except for small variation in genome sizes, AT contents, introns, and repeats. Phylogenetic analyses based on $54 \mathrm{cp}$ protein-coding genes examined by maximum likelihood and Bayesian analyses using amino acid and nucleotide datasets indicated that both Oedocladium and Oedogonium are polyphyletic groups. A positively selected gene (psbA) was identified in the two Oedocladium species and the terrestrial Oedogonium species, indicating that terrestrial Oedogoniales taxa may have undergone adaptive evolution to adjust to the difference in light intensity between aquatic and terrestrial habitats.

Conclusions: Our results enrich the data on cp genomes of the genus Oedogonium. The availability of these cp genomes can help in understanding the cp genome characteristics and resolve phylogenetic and evolutionary relationships of the order Oedogoniales.

Keywords: Oedogoniales, Chloroplast genome, Synteny, Polyphyletic group, Adaptive evolution

\section{Background}

The order Oedogoniales within the single family Oedogoniaceae includes three genera: Oedogonium Link ex Hirn, Oedocladium Stahl, and Bulbochaete Agardh [1-4]. More than 600 species have been described in this order, most of which can be found in fresh waters throughout the world, although

\footnotetext{
* Correspondence: liugx@ihb.ac.cn

${ }^{1}$ Institute of Hydrobiology, Chinese Academy of Sciences, Wuhan 430072, China

Full list of author information is available at the end of the article
}

Oedocladium species are mainly found on soil surfaces, a few species of Oedogonium are found in moist soil surfaces [4-14]. The presence of branches and hairs are the genus-level characteristics to distinguish this order; Oedogonium has simple and unbranched filaments, Bulbochaete has bulb-based hairs, and Oedocladium has branched filaments [5-14]. While some molecular phylogenetic studies on Oedogoniales have suggested that both Oedogonium and Oedocladium do not appear to be monophyletic, and the morphological criteria of Oedogoniales do not

(c) The Author(s). 2021 Open Access This article is licensed under a Creative Commons Attribution 4.0 International License, which permits use, sharing, adaptation, distribution and reproduction in any medium or format, as long as you give appropriate credit to the original author(s) and the source, provide a link to the Creative Commons licence, and indicate if changes were made. The images or other third party material in this article are included in the article's Creative Commons licence, unless indicated otherwise in a credit line to the material. If material is not included in the article's Creative Commons licence and your intended use is not permitted by statutory regulation or exceeds the permitted use, you will need to obtain permission directly from the copyright holder. To view a copy of this licence, visit http://creativecommons.org/licenses/by/4.0/ The Creative Commons Public Domain Dedication waiver (http://creativecommons.org/publicdomain/zero/1.0/) applies to the data made available in this article, unless otherwise stated in a credit line to the data. 
define natural groups, making its evolutionary position unclear [15-20].

Chloroplast (cp) genomes have been found to be ideal for phylogenetic analysis and molecular evolution studies owing to advantages such as low evolution rate and maternal inheritance [21-25], and plastome has been increasingly used for phylogenetic and evolutionary studies of green algae. For example, Claude Lemieux et al. [26] conducted cp phylogenetic analysis based on the cp genes of 61 chlorophytes and revealed that Trebouxiophyceae is not monophyletic. Zhang et al. [27] demonstrated the adaptive mechanism of sea-ice environment by analyzing the molecular evolution of an Antarctic sea ice alga Chlamydomonas sp. based on cp protein-coding genes. However, only four cp genomes of Oedogoniales are currently available in public databases $[28,29]$, restricting the phylogenetic analysis and molecular evolution studies based on cp genomes of this group.

Nucleotide substitution rates are often used as the criterion to reflect selection pressure. While nonsynonymous substitution rates $(\mathrm{dN})$ can cause amino acid change, synonymous substitution rates $(\mathrm{d} S)$ do not cause amino acid change. The $\mathrm{dN} / \mathrm{dS}$ ratio is the measure of natural selection acting on the protein. According to Yang [30], $\mathrm{dN} / \mathrm{dS}<1$ denotes negative purifying selection, $\mathrm{dN} / \mathrm{dS}=1$ signifies neutral evolution, and $\mathrm{dN} / \mathrm{dS}$ > 1 indicates positive selection [31]. As most of the plastid protein-coding genes undergo negative or purifying selection to maintain their function, they are conserved and have a low $\mathrm{dN} / \mathrm{dS}$ ratio. However, some genes might undergo positive selection in response to environmental changes, consequently presenting relatively high $\mathrm{dN} / \mathrm{dS}$ ratio [32-34].

In this study, the cp genomes of five Oedogonium species, were sequenced and an in-depth analysis of these genomes, including comparative analysis with previously reported Oedocladium and Oedogonium cp genomes, was performed. Furthermore, phylogenetic analysis and evolutionary study of the order Oedogoniales were conducted based on cp protein-coding genes and a positively selected gene was identified in Oedocladium species. The results of this study could be useful to understand the phylogenetic and evolutionary relationships of Oedogoniales.

\section{Results \\ Species identification}

The characteristics of the five Oedogonium taxa were list in Table 1. And the sizes of these characters of each taxa were list in Supplementary. Light microscopy of the five Oedogonium taxa were in Figs. 1 and 2. For strain FACHB-3309 (Fig. 1A-D), the main features were almost the same with Oe. dentireticulatum Jao [9], except for the apical and basal cells were not observed, and both the samples showed the same locality in Chongqing Province in China, it was identified as Oe. dentireticulatum Jao morphologically. For strain FACHB-3310 (Fig. $1 \mathrm{E}-\mathrm{I}$ ), it was identified as Oe. crispum (Hassall) Wittrock for the length-width ration was different from the similar Oe. autumnale Wittrock with larger length-width ration, and it was also different from the similar Oe. obesum (Wittrock) Hirn with the oospore nearly or completely filling the oogonium instead of not filling the oogonium [9, 14]. Strain FACHB-3313 (Fig. 2A-E) was identified as Oe. Capilliforme Kuetzing, Wittrock [9, 14], it differed with the similar Oe. plagiostomum Wittrock not with the thickened spore wall. With regard to strains FACHB-3311 (Fig. 2F) and FACHB-3313 (Fig. 2G), the entire sexual features could not be observed; however, the filaments of both of these strains were unbranched, indicating that they obviously belonged to the genus Oedogonium. In particular, strain FACHB-3313 exhibited unbranched rhizoids that resembled those of Oedocladium.

Table 1 Matrix of phenotypic traits scored for the five Oedogoniales strains. Character state definitions are below, unknown character states are notated as "?". Polymorphic conditions are indicated with multiple state numbers

\begin{tabular}{|c|c|c|c|c|c|c|c|c|c|c|c|c|c|c|}
\hline \multirow[t]{2}{*}{ Taxon (strain) } & \multicolumn{14}{|c|}{ Characters and states } \\
\hline & 1 & 2 & 3 & 4 & 5 & 6 & 7 & 8 & 9 & 10 & 11 & 12 & 13 & 14 \\
\hline Oe. dentireticulatum (FACHB-3309) & 0 & 2 & 0 & 0 & 1 & 0 & 0 & 1 & 1 & 1 & 1 & $?$ & $?$ & 0 \\
\hline Oe. crispum (FACHB-3310) & 0 & 0 & 1 & 0 & 0 & 1 & 1 & 0 & 0 & 0 & 0 & 0 & 0 & 0 \\
\hline Oe. sp. (FACHB-3311) & 0 & $?$ & $?$ & $?$ & $?$ & $?$ & $?$ & $?$ & $?$ & $?$ & $?$ & $?$ & $?$ & 0 \\
\hline Oe. capilliforme (FACHB-3312) & 0 & 1 & 2 & 0 & 0 & 0 & 1 & 2 & 0 & 0 & 0 & 0 & 1 & 0 \\
\hline Oe. sp. (FACHB-3313) & 0 & $?$ & $?$ & $?$ & $?$ & $?$ & $?$ & $?$ & $?$ & $?$ & $?$ & $?$ & $?$ & 0 \\
\hline
\end{tabular}

1-Habit: unbranched filaments (0); branched filaments (1). 2-Sex differentiation: monoecious species (0); dioecious, macrandrous species (1); dioecious, nannandrous, gynandrosporous species (2); dioecious, nannandrous, idioandrosporous (3). 3-Oogonium's morphology: subglobose (0); obovoid-globose (1); obovoid to subovoid (2). 4-If oospore filling the oogonium: same as oogonium, nearly or completely filling the oogonium (0). 5-Oospore wall ornamentation: smooth (0); outer layer reticulate and dentate, teeth spreading form reticulations (1). 6-Type of oogonial aperture: pore (0); circumcision (1). 7-Position of oogonial aperture: median to inframedian (0); superior (1). 8-If the antheridia single or continuous: single (0); 1 or 2 continuous (1); 2-7 in a series (2). 9-The number of sperm and the way of division: sperms 2, division horizontal (0); undefined (1). 10-Morphology of dwarf male: absent (0); on suffultory cells, stipes slightly curved, antheridia exteriors, 1 or 2 continuous (1); 11-Suffultory cells: uninflated (0); slightly inflated or inflated (1). 12-Basal cell: elongated (0); sub-hemispherical (1); undefined (2). 13-Terminal cell: obtuse (0); apiculate (1); 14-Vegetative cell's morphology: cylindrical (0) 


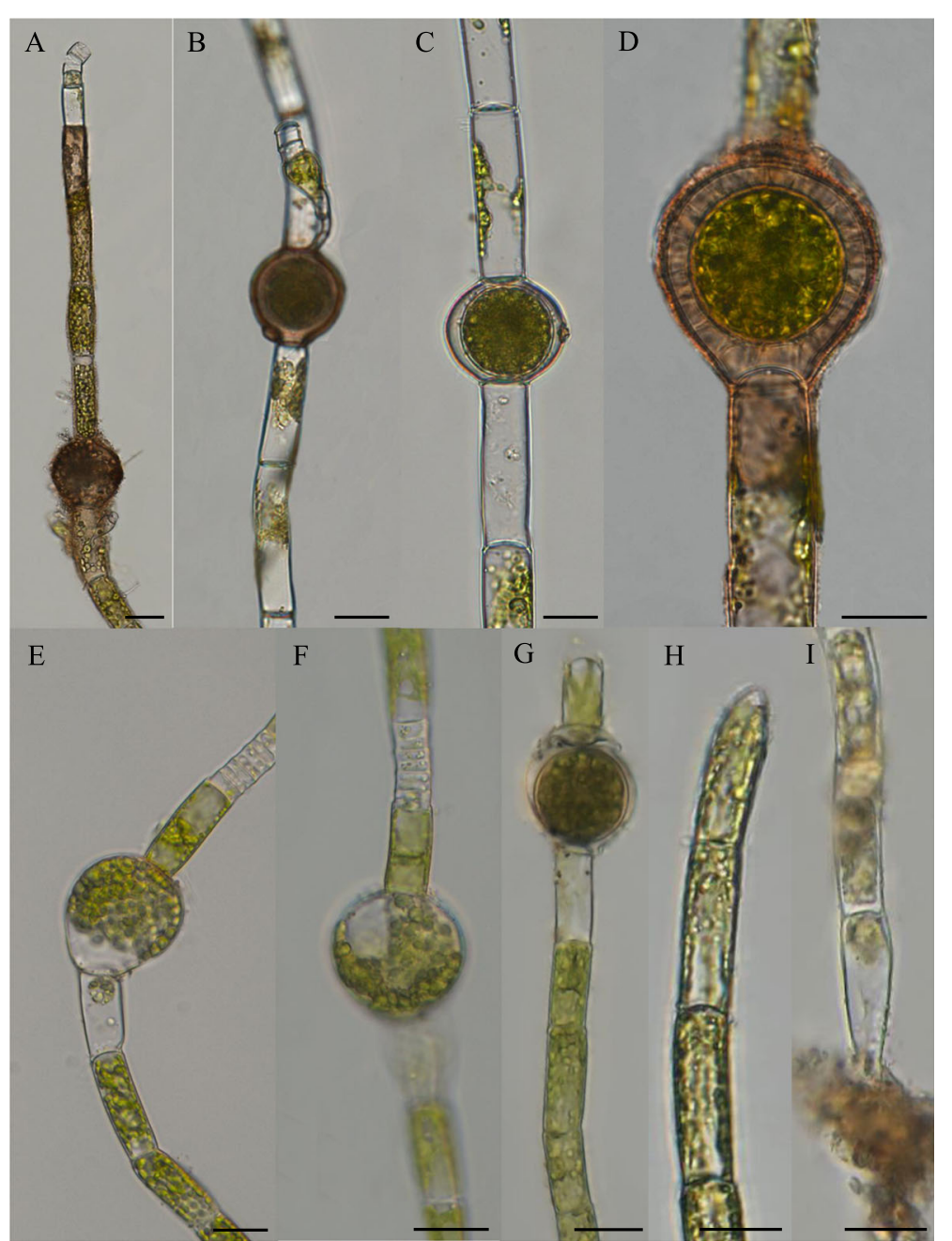

Fig. 1 Photos of habitat and light microscopy of Oe. dentireticulatum and Oe. crispum. A-D Oe. dentireticulatum. A Showing the unbranched filament with oogonium, dwarf males and androsporangia. B Showing the dwarf male with two seriate and the oogonium. C Showing the median pore. D Sowing the oospore with dentate teeth. E-I Oe. crispum. E. Showing the unbranched filament with oogonium and antheridium. $\mathbf{F}$ Showing the sperms division horizontal, sperms 2. G Showing the oogonium single, obovoid-globose, operculate, division superior. H Terminal cell apically obtuse. I Elongated basal cell

\section{General characteristics and comparison of Oedogoniales cp genomes}

Table 2 summarizes the cp genomes characteristics of the five newly included Oedogonium species, three reported Oedocladium taxa and one Oedogonium species. The complete cp genomes of the nine species of Oedogoniales ranged from $146,367 \mathrm{bp}$ (Oe. crispum) to 204,438 bp (O. carolinianum) in length. All of the five Oedogonium cp genomes displayed typical circular mapping with a large single copy (LSC) region $(76,475-$ 98,887 bp), a small single copy (SSC) region (43,305$58,055 \mathrm{bp}$ ), and two inverted repeats (IR) regions (12,808-35,492 bp) (Supplementary Figs. S1, S2, S3, S4, S5). The overall AT content in each $\mathrm{cp}$ genome was comparable and showed a little difference among the species, ranging from $69.98 \%$ (strain FACHB-3311) to
$72.66 \%$ (O. prescottii); besides, difference was noted in coding proportion, which varied from $51.4 \%$ (O. carolinianum) to $69.5 \%$ (O. prescottii). The cp genomes of six Oedogonium species were moderately compact relative to those of the Oedocladium species. All the cp genomes contained 68 protein-coding genes and three rRNA genes, except for the cp genome of Oe. cardiacum, which have two additional genes $(d p o \mathrm{~B}$ and $i n t)$ located in the IR region. With respect to tRNA, the cp genomes showed slight difference as follows: Oe. cardiacum exhibited two additional $\operatorname{trnR}(\mathrm{ccu})$ located in the IR regions and Oe. dentireticulatum (strain FACHB-3309) presen; ted an additional $\operatorname{trnR}(\mathrm{ccu})$ in the LSC region; both Oe. crispum and Oe. sp. (strain FACHB-3313) contained two additional $\operatorname{trnR}(\mathrm{ccg})$ in the IR regions and $O$. carolinianum has an additional trnR(ccg) in the LSC 


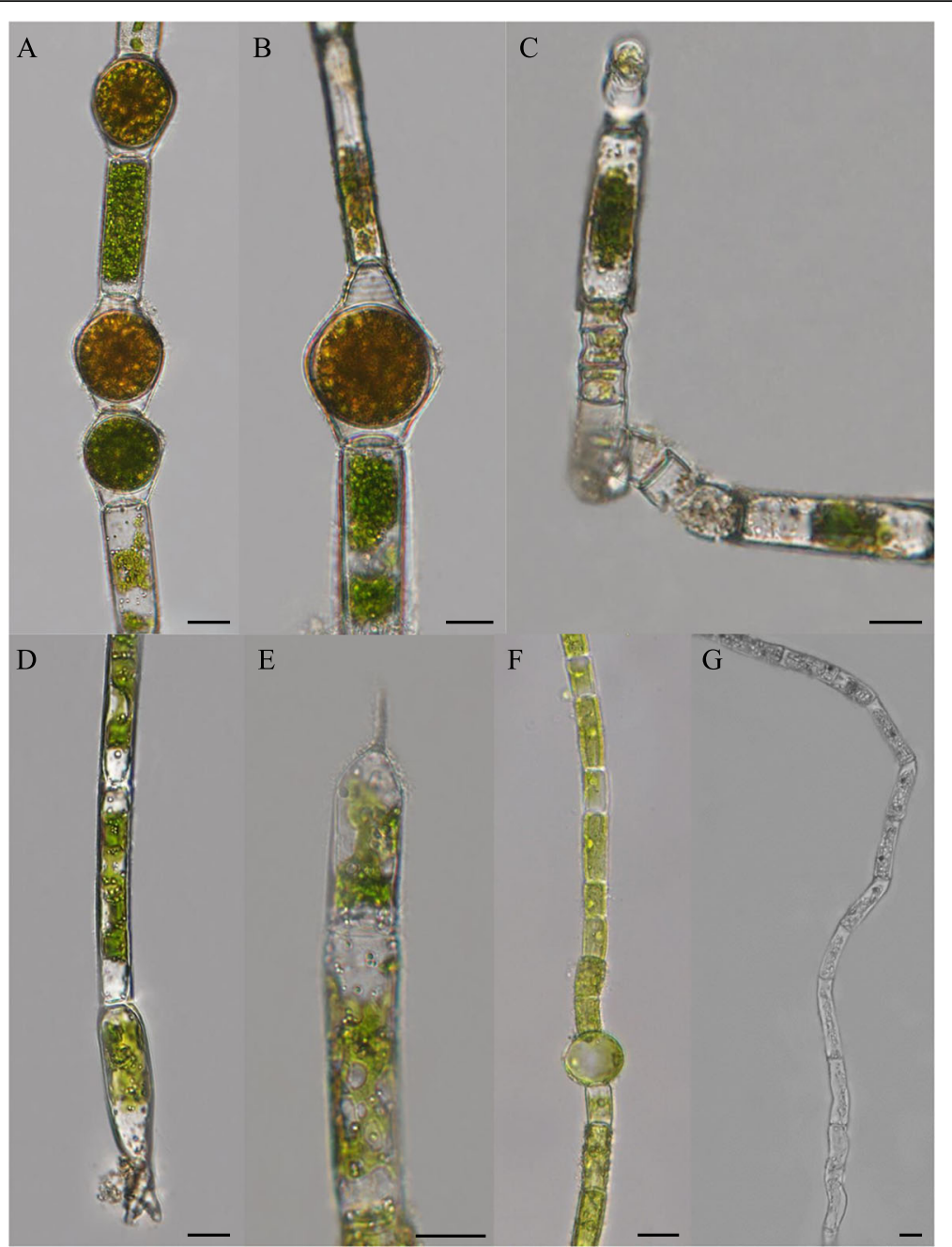

Fig. 2 Photos of habitat and light microscopy of Oe. capilliforme and two undefined species. A-E Oe. capilliforme. A Unbranched female filament with oogonium single or 2-continues, oogonium with superior pore. B Oogonium with median pore. C Antheridium in 2-7 in a series, with sperms 2, division horizontal. D Apiculate terminal cell. E Elongated basal cell. F Oe. sp. (strain FACHB-3311), showing the unbranched filament with young oogonium. G Oe. sp. (strain FACHB-3313), unbranched filament with rhizoid (4\% formaldehyde fixed sample). Scale bars: $20 \mu \mathrm{m}$

region; and $O$. carolinianum has an additional trnS(gga) in the LSC region. Sequence repeats of more than $30 \mathrm{bp}$ were less frequent $(3.9-4.9 \%)$ in the cp genomes of the five Oedogonium species when compared with those in the two O. carolinianum cp genomes, but were more frequent, when compared with those in the Oe. cardiacum cp genome.

\section{Introns content and insertion sites}

The introns content and insertion sites of the nine Oedogoniales cp genomes are listed in Table 2 and Supplementary Tables S1 and S2. The nine cp genomes significantly differed with respect to the introns content. Oe. sp. (strain FACHB-3311) has the maximum introns content with 26 group I introns and 11 group II introns. When compared with the other six Oedogonium cp genomes, multiple intron losses were observed in the $\mathrm{cp}$ genome of Oe. crispum (strain FACHB-3310), with four

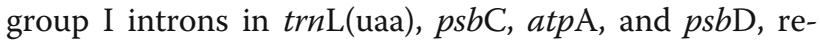
spectively, and four group II introns in $p s b \mathrm{I}$, pet $\mathrm{D}, p s a \mathrm{C}$, and $p s a \mathrm{~B}$, respectively. Besides, similar to O. prescottii, Oe. crispum also exhibited introns losses in $p s b \mathrm{~A}$. Oe. sp. (strain FACHB-3311) presented two additional group II introns in $c h l \mathrm{~B}$ and $c h l \mathrm{~L}$, introns were first observed in them. All the nine cp genomes included group I introns in $\operatorname{trn} \mathrm{L}$ (uaa), which is common across all algal lineages and is considered to originate from the common ancestor of $\mathrm{cp}$ [35]. The nine $\mathrm{cp}$ genomes showed a certain variation in insertion sites. The common group I introns in $\operatorname{trn} \mathrm{L}$ (uaa) and group II introns in $p e t \mathrm{~B}, p s a \mathrm{C}$, and $p s b \mathrm{I}$ (only strain FACHB-3311 lost the intron in psbI) showed the same insertion sites. With regard to the other genes with introns, the insertion sites in different species showed similarities and variations. For instance, in $p s b \mathrm{~A}$, 
Table 2 General features of nine oedogonialean chloroplast genomes

\begin{tabular}{|c|c|c|c|c|c|c|c|c|c|}
\hline Genomic Feature & $\begin{array}{l}\text { O. } \\
\text { prescottii }\end{array}$ & $\begin{array}{l}\text { O. } \\
\text { carolinianum } \\
\text { (FACHB-2453) }\end{array}$ & $\begin{array}{l}\text { O. } \\
\text { carolinianum }\end{array}$ & $\begin{array}{l}\text { Oe. } \\
\text { cardiacum }\end{array}$ & $\begin{array}{l}\text { Oe. } \\
\text { dentireticulatum }\end{array}$ & $\begin{array}{l}\text { Oe. } \\
\text { crispum }\end{array}$ & $\begin{array}{l}\text { Oe.sp. } \\
\text { (FACHB- } \\
3311 \text { ) }\end{array}$ & $\begin{array}{l}\text { Oe. } \\
\text { capilliforme }\end{array}$ & $\begin{array}{l}\text { Oe.sp. } \\
\text { (FACHB- } \\
3313 \text { ) }\end{array}$ \\
\hline \multicolumn{10}{|l|}{ Size (bp) } \\
\hline Total & 154,978 & 200,832 & 204,438 & 196,547 & 159,341 & 146,367 & 187,104 & 195,349 & 179,946 \\
\hline $\mathbb{R}$ & 12,808 & 22,275 & 23,748 & 35,492 & 19,159 & 13,284 & 25,841 & 35,138 & 26,999 \\
\hline LSC & 80,821 & 98,462 & 98,887 & 80,363 & 77,718 & 76,475 & 86,403 & 80,003 & 80,347 \\
\hline SSC & 48,542 & 57,820 & 58,055 & 45,200 & 43,305 & 43,324 & 49,019 & 45,070 & 45,601 \\
\hline$A+T(\%)$ & 72.66 & 70.51 & 70.2 & 70.5 & 71.46 & 72.28 & 69.98 & 70.64 & 71.23 \\
\hline $\begin{array}{l}\text { Coding } \\
\text { proportion }^{a}\end{array}$ & $67.0 \%$ & $52.7 \%$ & $51.4 \%$ & $55.9 \%$ & $64.1 \%$ & $69.5 \%$ & $54.8 \%$ & $52.8 \%$ & $55.9 \%$ \\
\hline Gene $(+/-)^{\mathrm{bc}}$ & $49 / 60$ & $50 / 61$ & $50 / 61$ & $52 / 63$ & $50 / 59$ & $50 / 61$ & $49 / 60$ & $49 / 60$ & $50 / 61$ \\
\hline $\begin{array}{l}\text { Protein-coding } \\
\text { genes(number/ } \\
\text { proportion) }\end{array}$ & $\begin{array}{l}68 \\
29 / 43\end{array}$ & $\begin{array}{l}68 \\
28 / 44\end{array}$ & $\begin{array}{l}68 \\
28 / 44\end{array}$ & $\begin{array}{l}70 \\
31 / 45\end{array}$ & $\begin{array}{l}68 \\
29 / 43\end{array}$ & $\begin{array}{l}68 \\
29 / 43\end{array}$ & $\begin{array}{l}68 \\
29 / 43\end{array}$ & $\begin{array}{l}68 \\
29 / 43\end{array}$ & $\begin{array}{l}68 \\
29 / 43\end{array}$ \\
\hline $\begin{array}{l}\text { rRNA(number/ } \\
\text { proportion) }\end{array}$ & 3 & 3 & 3 & 3 & $3 / 3$ & $3 / 3$ & $3 / 3$ & $3 / 3$ & $3 / 3$ \\
\hline $\begin{array}{l}\text { tRNA(number/ } \\
\text { proportion) }\end{array}$ & $\begin{array}{l}28 \\
17 / 14\end{array}$ & $\begin{array}{l}30 \\
19 / 14\end{array}$ & $\begin{array}{l}30 \\
19 / 14\end{array}$ & $\begin{array}{l}29 \\
18 / 15\end{array}$ & $\begin{array}{l}29 \\
18 / 14\end{array}$ & $\begin{array}{l}29 \\
18 / 15\end{array}$ & $\begin{array}{l}28 \\
17 / 14\end{array}$ & $\begin{array}{l}28 \\
17 / 14\end{array}$ & $\begin{array}{l}29 \\
18 / 15\end{array}$ \\
\hline Introns & 6 & 15 & 17 & 21 & 22 & 8 & 37 & 24 & 30 \\
\hline Group I (no.) & 1 & 5 & 7 & 17 & 18 & 4 & 26 & 20 & 25 \\
\hline Group II (no.) & 5 & 10 & 10 & 4 & 4 & 4 & 11 & 4 & 5 \\
\hline Repeats $^{\mathrm{d}}(\%)$ & 4.8 & 8.9 & 11.3 & 1.3 & 3.9 & 4.0 & 4.7 & 3.3 & 4.9 \\
\hline $\begin{array}{l}\text { Accession } \\
\text { number }\end{array}$ & MT364368 & MT364369 & NC_031510 & EU677193 & MW250871 & MW250872 & MW250873 & MW250874 & MW250875 \\
\hline
\end{tabular}

${ }^{\mathrm{a}}$ The coding proportion only includes all annotated protein-, rRNA-, and tRNA-coding regions; ${ }^{\mathrm{b}}$ Gene and CDS numbers do not include ORF genes; ${ }^{\mathrm{C}}$ The plusminus sign means number of genes in plus strain (left side of slash) or minus strain (rightside of slash). ${ }^{\mathrm{d}}$ Non-overlapping repeat elements were mapped on each genome with RepeatMasker using as input sequences the repeats $\geq 30 \mathrm{bp}$ identified with Vmatch

the number of introns (introns in psbA are all group I) differed among the species, whereas the insertion sites of the first intron in Oe. dentireticulatum (strain FACHB3309), Oe. sp. (strain FACHB-3311), and Oe. sp. (strain FACHB-3313) were identical. The two O. carolinianum were the same; however, the insertion site of the first intron in Oe. capilliforme was similar to that of the fourth intron in Oe. dentireticulatum and sp. (strain FACHB3311).

Synteny analysis and average nucleotide identity analysis ProgressiveMauve was used to analyze the Oedogoniales cp genomes synteny, with Oe. cardiacum used as a reference to compare gene order among the cp genomes (Fig. 3). More than 19 locally collinear blocks (LCBs) were identified in the cp genomes of the nine species of Oedogoniales, including six taxa from Oedogonium and three taxa from Oedocladium. The nine cp genomes showed high degree of syntenic conservation on the whole, with Oe. capilliforme exhibiting high similarity to Oe. cardiacum, and Oe. dentireticulatum resembling Oe. sp. (strain FACHB-3311). However, some rearrangements and inversions were still observed among certain short LCBs mainly owing to the inversion or loss of introns. The genes order and number were almost identical except for that an inversion between trnE(uuc) and pet $\mathrm{L}$ with a length of less than $3 \mathrm{~kb}$ and including the genes pet $\mathrm{D}$ and trn $\mathrm{R}(\mathrm{ucg})$ was detected in $O$. carolinianum (MT364369) and O. carolinianum (NC_031510).

The average nucleotide identity (ANI) of the nine species of Oedogoniales was calculated using FastANI (Supplementary Fig. S6). Oe. crispum showed high ANI with Oe. dentireticulatum and Oe. sp. (strain FACHB-3311) (90.64 and 90.56\%, respectively), Oe. dentireticulatum was similar to Oe. sp. (strain FACHB-3311) with $92.57 \%$ ANI, and Oe. capilliforme was similar to Oe. cardiacum with $97.03 \%$ ANI.

\section{IR expansion and contraction}

The IR boundary regions of the nine species of Oedogoniales were compared as illustrated in Fig. 4. Oe cardiacum and Oe. capilliforme (strain FACHB-3312) showed larger IRs reaching 35,000 bp, whereas Oe. crispum and O. prescottii exhibited smaller IRs reaching 13,284 and $12,808 \mathrm{bp}$, respectively. The IRs of all the nine cp genomes contained the same four protein-coding genes, three tRNAs, and three rRNAs. However, in Oe. crispum and Oe. sp. (strain FACHB-3313), an additional 


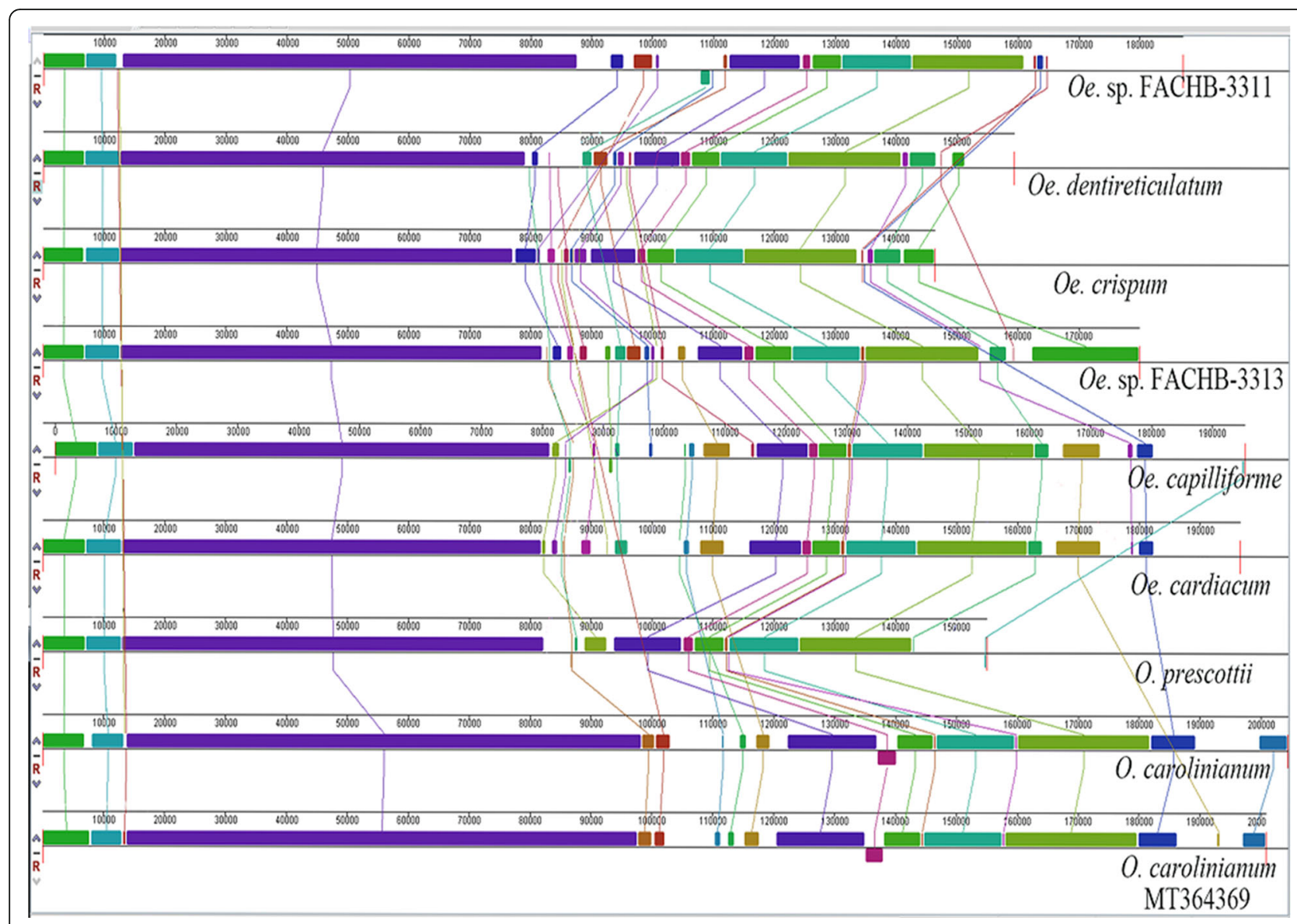

Fig. 3 Synteny comparison of Oedogoniales algae chloroplast genomes using progressiveMauve. The coloured syntenic blocks are local collinear blocks; blocks above the centre line indicate they are on the same strand, and blocks below the center line indicate they are on the opposite strand

$\operatorname{trn} \mathrm{R}(\mathrm{ccg})$ was observed between $p s b \mathrm{~A}$ and $r b c \mathrm{~L} ;$ Oe. cardiacum included two additional protein-coding genes (int and $d p o \mathrm{~B})$ and one tRNA $(\operatorname{trnR}(\mathrm{ccu}))$; and the IRa of four cp genomes included parts of the $5^{\prime}$-end of $\operatorname{ccs} \mathrm{A}$ (390 bp in Oe. cardiacum, Oe. capilliforme, and O. prescottii and $383 \mathrm{bp}$ in Oe. crispum).

The nine Oedogoniales cp genomes showed high conservation at four regional boundaries, with little variation. The LSC/IRb junctions (JLBs) in the cp genomes of Oe. cardiacum, Oe capilliforme, O. prescottii, and Oe. sp. (strain FACHB-3311) were located in trnR(ucu); as a result, $2 \mathrm{bp}$ of the 3 '-end of this gene were a part of the IR region. In Oe. sp. (strain FACHB-3311), the IR region contained $6 \mathrm{bp}$ of the $3^{\prime}$-end of $\operatorname{trnR}(\mathrm{ucu})$, and in the other five cp genomes, the LSC/IRb boundaries occurred between $\operatorname{trnR}(\mathrm{ccu})$ and $p s b \mathrm{~A}$. The IRb/SSC boundaries in all the nine cp genomes occurred between $\operatorname{trn} \mathrm{L}$ (caa) and $p s a \mathrm{~A}$, and the SSC/IRa junctions were located in rpoA. The IRa/LSC junctions (JSAs) of the two O. carolinianum cp genomes occurred between psbA and $c c s \mathrm{~A}$, while those of the other seven genomes were located in
ccsA, with $390 \mathrm{bp}$ of the $5^{\prime}$-end of this gene being a part of the IR region in Oe. cardiacum, Oe. capilliforme, and O. prescottii, and 383, 388, 608, and 389 bp of the $5^{\prime}$-end of this gene being a part of the IR region in Oe. crispum, strain FACHB-3313, strain FACHB-3311, and Oe. dentireticulatum, respectively.

\section{Phylogenetic analysis and adaptive evolution analysis}

Phylogenetic assays based on $54 \mathrm{cp}$ protein-coding genes were conducted using maximum likelihood (ML) and Bayesian analyses with amino acid and nucleotide datasets, which generated two kinds of phylogenetic trees showing the same results (Figs. 5 and 6). Phylogenetic trees based on amino acid and nucleotide datasets both indicated that the nine species of Oedogoniales clustered into three clades Oe. sp. (MW250873) formed a separate clade with absolute high support value, the two O. carolinianum clustered together and formed another clade, and the other six Oedogoniales formed the third clade. With regard to the third clade, the two datasets showed a little difference in the location of $O$. prescottii. Based 

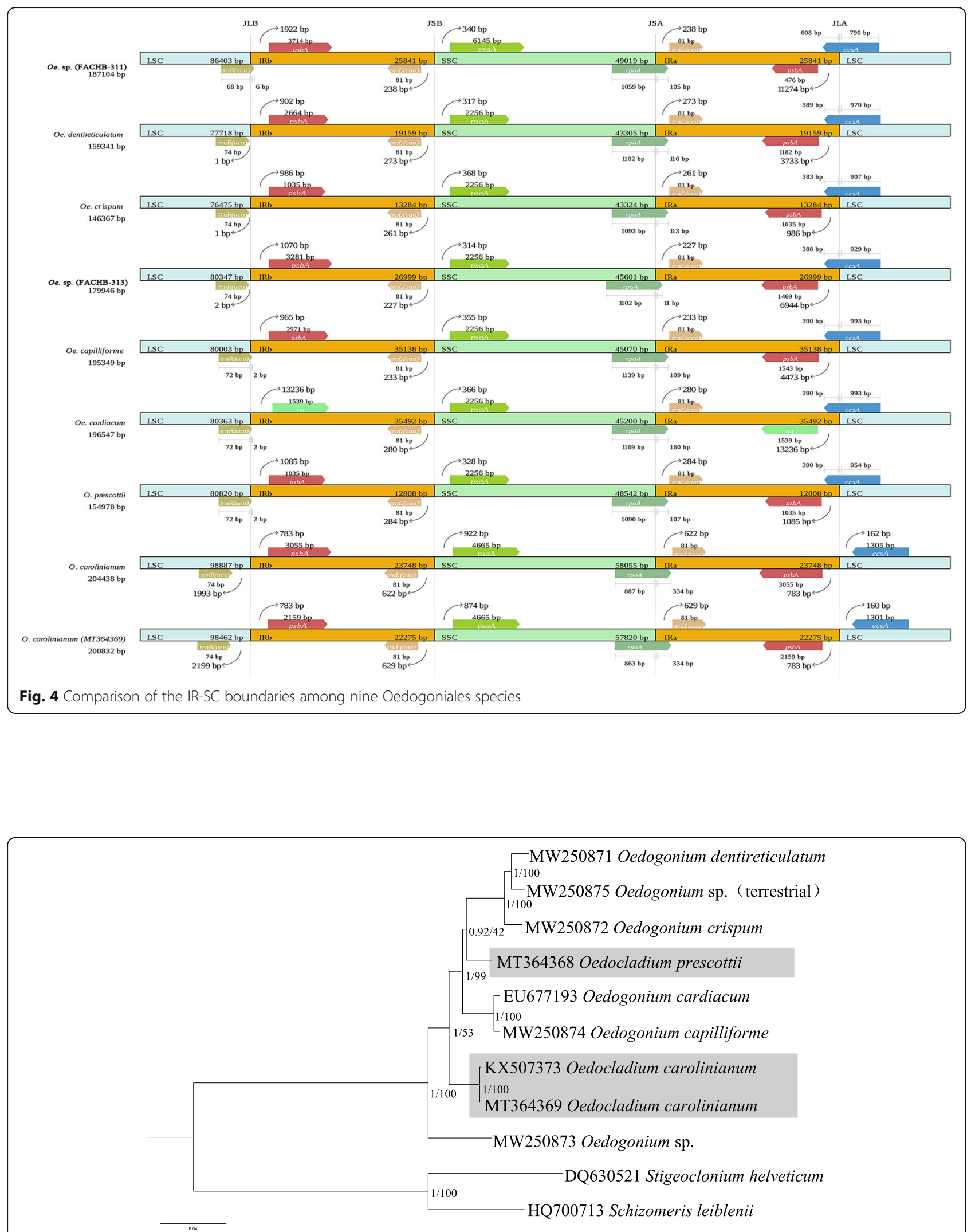

Fig. 5 Phylogenetic tree based on 54 chloroplast genes was generated by the amino acid data sets. Numbers on the left and right side at the branches represent Bayesian posterior probabilities and bootstrap values, respectively. Scale bar indicates substitutions per site 


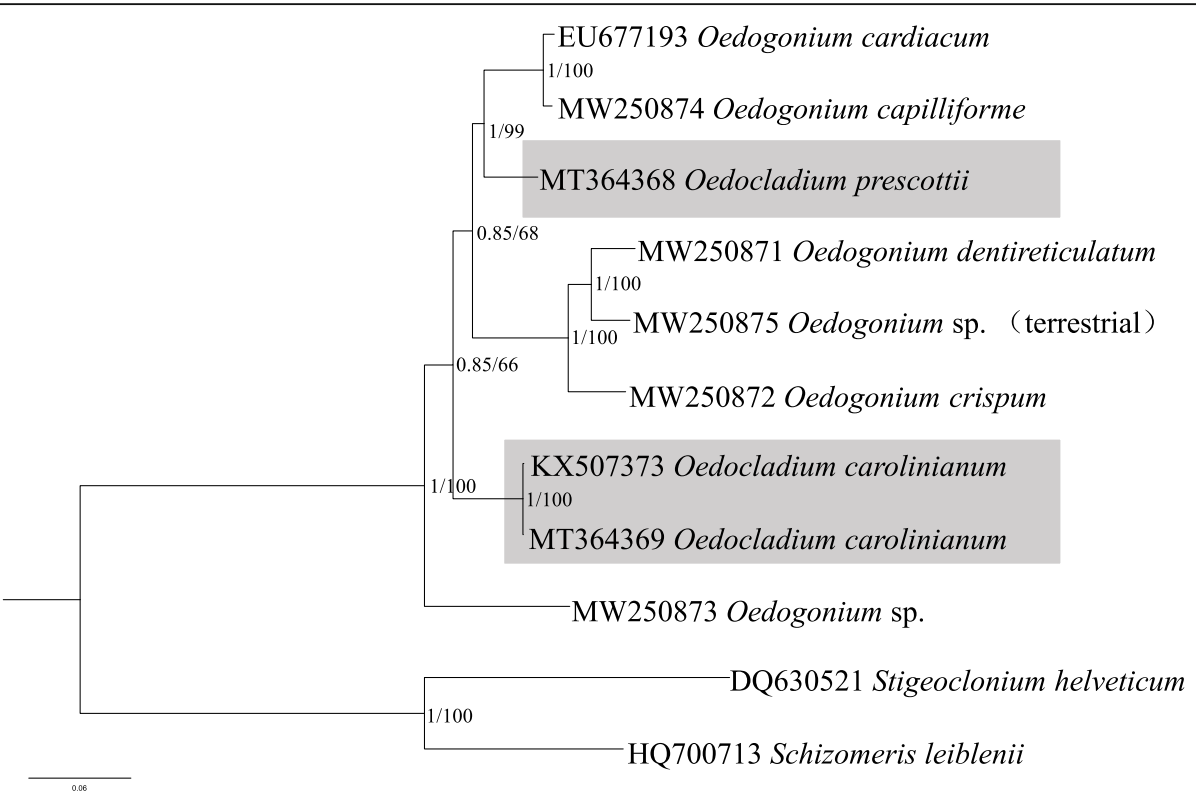

Fig. 6 Phylogenetic tree based on 54 chloroplast genes was generated by the nucleotide data sets. Numbers on the left and right side at the branches represent Bayesian posterior probabilities and bootstrap values, respectively. Scale bar indicates substitutions per site

on nucleotide dataset, $O$. prescottii clustered with Oe. cardiacum and Oe. capilliforme, whereas according to the amino acid dataset, O. prescottii clustered with Oe. dentireticulatum, Oedogonium sp. (MW250875), and Oe. crispum. A total of 26 taxa, including the newly added five Oedogonium taxa, were included in the $18 \mathrm{~S} \mathrm{rDNA}$ phylogeny (Supplementary Fig. S7). The phylogenetic tree showed that species of Bulbochaete was separated with Oedogonium and Oedocladium with absolutely high support value, and the species of Oedocladium formed two branches separated by two species of Oedogonium, the five newly included Oedogonium species separated with each other distributed in the other small clades. All these results indicated that both Oedocladium and Oedogonium are polyphyletic, which is in accordance with that reported in a previous study [36].

Based on the ML method of 54 chloroplast proteincoding genes, the value of $\mathrm{dN}$ and $\mathrm{dS}$ were compared between terrestrial and aquatic species of Oedogoniales. (Supplementary Table S3). No genes showed significantly different between the two group of algae at the levels of $\mathrm{dN}$ and $\mathrm{dS}$. The ML method is a pairwise approach to estimate the $\mathrm{dN} / \mathrm{dS}$ ratio, a $\mathrm{dN} / \mathrm{dS}$ ratio may indicate in one or both species, and some specific sites under positive selection may remain undetected [37]. Positive selection analysis was performed based on branch-site model, and the null and alternative models were compared. The null model considered that the foreground branch only has $\mathrm{dN} / \mathrm{dS}=1$, and the alternative model assumed that sites on the foreground branch have $\mathrm{dN} / \mathrm{dS}>1$ (positive selection). When the two Oedocladium species and MW250875 were labelled as the foreground branch, the FDR-adjusted $P$ value of $p s b$ A was less than 0.05 (Table 3). Based on Bayes empirical Bayes (BEB) assay, it indicated that psbA may possibly contain sites under positive selection, with 291SER showing posterior probability higher than $99 \%$. However, owing to the lack of related functional sites information on closely related species such as Chlamydomonas reinhardtii and Stigeoclonium helveticum in UniProt, the positively selected sites of $p s b A$ require further investigation.

\section{Discussion}

In this study, we investigated five Oedogonium isolates from China, of which strains FACHB-3309, FACHB3310, and FACHB-3312 were identified as Oe. dentireticulatum, Oe. crispum, and Oe. capilliforme, respectively.

Table 3 Positively selected sites in terrestrial Oedogoniales species (Oedocladium species and Oedogonium sp. (MW250875))

\begin{tabular}{llllccll}
\hline Gene & InL H0 & InL HA & df & $\operatorname{InL} \mathbf{2} \times \mid$ (HA-H0) & P value & FDR & Positive selected sites under BEB analysis \\
\hline psbA & -2309.7534 & -2299.2283 & 1 & 21.0502 & 0.0000 & 0.0002 & 291S-0.998299G-0.920 \\
\hline
\end{tabular}

Number behind hyphen is the posterior probability of BEB analysis 
Strains FACHB-3311 and FACHB-3313 were considered to belong to the genus Oedogonium owing to their unbranched filaments; however, they could not be identified at species level owing to their lack of entire sexual characters.

Comparative analyses of the nine Oedogoniales cp genomes showed highly conserved structures and gene numbers. The cp genomes of the newly sequenced five Oedogonium species were found to share the same structure as the previously reported Oedogoniales cp genomes, and the structures of the tetrad were not altered, but were different from the other two orders in the OCC clade (the IR is obliterated in the reported cp genomes in Chaetophorales and Floydiella of Chaetopeltidales). It has been indicated IR loss may be a synapomorphy marking the common ancestry of Chaetophorales and Chaetopeltidales [38]. The total length of these $\mathrm{cp}$ genomes was observed to vary within a relatively large range, extending from 146,367 bp (Oe. crispum) to 204,438 bp (O. carolinianum), which may be the result of contraction and expansion of IR regions and proportion of non-coding sequences, such as the introns content. Furthermore, the nine cp genomes showed highly conserved protein-coding genes and rRNAs number; however, they presented a slight difference in the tRNAs content. With regard to the introns content, the nine cp genomes exhibited relative variation, and the number of group I introns significantly differed, mainly owing to the diversity in the introns in psbA. In particular, introns (group II) were observed for the first time in chlB and chlL in Oe. dentireticulatum. All the nine cp genomes retained the group I introns in $\operatorname{trn} \mathrm{L}$ (uaa) and group II introns in pet $\mathrm{D}$ and $p s a \mathrm{C}$, and shared the same insertion sites. With regard to the other genes with introns, the insertion sites of different species showed similarities and variations.

Synteny analyses revealed a relatively high degree of syntenic conservation among the nine cp genomes, and only one inversed segment was detected in O. carolinianum FACHB-2453 and O. carolinianum UTEX LB 1686. The other variations were mainly owing to the introns, and no structural variation was observed in the six Oedogonium species. The results of FastANI also supported the findings of synteny analyses, indicating that Oe. capilliforme had high similarity with Oe. cardiacum, and Oe. dentireticulatum resembled strain FACHB-3311.

IR regions are the most conserved regions in the $\mathrm{cP}$ genomes. Frequent expansions and contractions at the junctions of SSC and LSC with IRs illustrate the relationships among the taxa and have been recognized as evolutionary signals [39-43]. The nine species of Oedogoniales examined in the present study showed only a few variations at the junctions. When compared with the two $O$. carolinianum, $O$. prescottii showed higher similarities to the five Oedogonium species, and the five Oedogonium species were similar to each other. The IR regions of $O$. prescottii and Oe. crispum presented a contraction, when compared with those of the other Oedogoniales taxa, and the cp genomes of both $O$. prescottii and Oe. crispum exhibited the shortest length. Previous studies have indicated that IR expansion and contraction frequently result in variations in genome size, which can be applied to phylogenetics and genome evolution analyses [40,41,44], and gene conversion during speciation is considered to be responsible for small IR expansions or contractions [40, 41, 45-47].

Phylogenetic studies based on $54 \mathrm{cp}$ protein-coding genes assayed using ML and Bayesian analyses with amino acid and nucleotide datasets and 18S rDNA all showed that Oedocladium and Oedogonium are polyphyletic, which is in accordance with that reported previously. However, the support value based on nucleotide dataset and $18 \mathrm{~S}$ rDNA was not very high at the basal node, probably owing to the lack of sufficient representative taxa for this group as well as different evolutionary rates of the amino acid sequence and nucleotide data. Previous studies have proposed that larger sample sizes can substantially improve the phylogenetic results [48].

Positively selected genes are known to play a key role in adaptation to different environments and speciation [49-53], and it is necessary to understand the adaptive evolutionary history of Oedocladium species. The results of the present study showed that 291SER of $p s b$ A may be under positive selection with posterior probability higher than 99\%. The genus Oedocladium (terrestrial) is presumed to have partly originated from Oedogonium species, which grow on moist soil surface and present underground filaments with slightly unbranched rhizoids [9]. The psbA encodes the photosystem II reaction center protein $\mathrm{D} 1$, which is one of the two reaction center proteins of photosystem II. Photosystem II is the first link in the chain of photosynthesis, and captures photons and uses the energy to extract electrons from water molecules [54].It has been reported that the genes in the cp genome (including psbA) of Curcuma sp. show adaptive evolution to adapt to the changes in light conditions [55], and that the green alga Chlamydomonas sp. ICE-L underwent adaptive evolution to adapt to extreme polar environment [27]. We speculate that the Oedocladium species and terrestrial Oedogonium species could have partly originated from the aquatic Oedogonium species, and might have undergone adaptive evolution during this process to adapt to the difference in light intensity between aquatic and terrestrial habitats. Nevertheless, more genomic data, especially for terrestrial species, may help to verify these hypotheses and further understand the phylogenetic and evolutionary relationships of the order Oedogoniales. 


\section{Conclusion}

The present study determined the cp genomes of five Oedogonium speciesand revealed that the overall structure and gene contents of the Oedogoniales cp genomes were relatively conserved, except for some variations in genome sizes, AT contents, introns, and repeats. Phylogenetic analysis based on $54 \mathrm{cp}$ protein-coding genes and $18 \mathrm{~S}$ rDNA genes all indicated that both Oedogonium and Oedocladium are polyphyletic. The positively selected gene in the two Oedocladium species was identified, and the terrestrial Oedogonium species were speculated to have undergone adaptive evolution to adapt to the difference in light intensity between aquatic and terrestrial habitats. These findings not only strengthen our understanding of Oedogoniales cp genomes, but also help us to comprehend the phylogenetic and evolutionary relationships of the order Oedogoniales.

\section{Methods \\ Sampling, culture conditions, DNA extraction, and morphological observation}

The strains described in this study were isolated from water or soil samples, and have been deposited to the Freshwater Algae Culture Collection at the Institute of Hydrobiology (FACHB collection), Wuhan, Hubei Province, China. Strain FACHB-3309 was collected from a paddy field in Hechuan $\left(29^{\circ} 50^{\prime} 15^{\prime \prime} \mathrm{N}, 106^{\circ} 12^{\prime} 46^{\prime \prime} \mathrm{E}\right)$, Chongqing Province, China, in March 2019. Strain FACHB-3310 was collected from a pond in Lvliang $\left(37^{\circ} 34^{\prime} 20^{\prime \prime} \mathrm{N}, 112^{\circ} 12^{\prime} 29.25^{\prime \prime} \mathrm{E}\right)$, Shanxi Province, China, in July 2018. Strain FACHB-3311 was collected from a pond in Wuhan $\left(30^{\circ} 3^{\prime} 46^{\prime \prime} \mathrm{N}, 114^{\circ} 23^{\prime} 56^{\prime \prime} \mathrm{E}\right)$, Hubei Province, China, in June 2019. Strain FACHB-3312 was collected from a ditch in Wuhan $\left(30^{\circ} 33^{\prime} 2^{\prime \prime} \mathrm{N}, 114^{\circ} 25^{\prime}\right.$ 48" E), Hubei Province, China, in April 2019. Strain FACHB-3313 was collected from damp soil in a park in Haikou $\left(20^{\circ} 2^{\prime} 23^{\prime \prime} \mathrm{N}, 110^{\circ} 21^{\prime} 1^{\prime \prime} \mathrm{E}\right)$, Hainan Province, China, in December 2018. All the strains were grown at $25^{\circ} \mathrm{C}$ in liquid BG11 medium under a $12 / 12$-h light/dark cycle. The genomic DNA was extracted using a Universal DNA Isolation Kit (Axygen, Suzhou, China) [56]. An Olympus BX53 (Tokyo, Japan) light microscope equipped with an Olympus DP80 digital camera and CellSens standard image analysis software (Tokyo, Japan) were used for morphological examination. The characteristics of the five species were summarized in Table 1.

Library preparation, sequencing, genome assembly, and annotation

A NEB Next Ultra DNA Library Prep Kit for Illumina (New England Biolabs, Ipswich, MA, USA) was used for preparing sequencing libraries, which were sequenced on an Illumina NovaSeq 6000 platform by a commercial provider (Novogene, Beijing, China). The methods of genome assembly and annotation have been described elsewhere [36, 57]. The raw data were trimmed using SOAPnuke software [58] to remove the low-quality and the adapter sequences (the reads of the five species were with a mean length about $150 \mathrm{bp}$ ) and then assembled using SPAdes [59]. The resulting assembly contigs were considered to have originated from the $\mathrm{cp}$ genome if the (1) BLAST searches in publicly available cp genomes returned Chlorophyta species with significant e-values (1e-5); (2) GC content of the contigs was less than $45 \%$ (the GC content of previously sequenced green algal $\mathrm{cp}$ genomes is typically less than $45 \%$ ); and (3) sequencing depth was more than 100-fold coverage. Subsequently, trimmed clean reads were aligned to the resulting assembly contigs using BWA-MEM [60]. If the reads mapped to two contigs, the order of the contigs was determined and one sequence was produced, which was confirmed by Sanger dideoxy sequencing. The cp genomes were initially annotated using GeSeq [61] with the reported Oedogoniales cp genomes as references. Protein-coding and ribosomal RNA genes were further polished using Blast with genes from the available Oedogoniales cp genomes. The tRNA genes were identified using tRNAscan-SE [62]. BLAST was used to refine the annotation results. Intron boundaries were determined by comparing intron-containing genes with homologs without introns, and intron subgroup affiliation was determined by modelling intron secondary structures [63, 64] using RNAweasel tool [65]. Forward and palindromic repeats larger than $30 \mathrm{bp}$ were searched using Vmatch software (http://www.vmatch.de/) with the options -f - $\mathrm{p}-\mathrm{l}-\mathrm{h}$-allmax and masked in the genome sequence by RepeatMasker (http://repeatmasker.org) running under the NCBI/RMBLAST $(2.9 .0+)$ search engine (http://blast.advbiocomp.com). The annotated sequences have been deposited to the NCBI GenBank database under the accession numbers MW250871MW250875 (corresponding to strains FACHB-3309FACHB-3313, respectively). Genome maps were generated using OrganellarGenomeDRAW [66].

\section{Phylogenetic analysis}

Phylogenetic analysis of the algal strains was performed by examining the sequences of $\mathrm{cp}$ proteincoding genes based on amino acid and nucleotide datasets and the $18 \mathrm{~S}$ rDNA. The amino acid and nucleotide datasets of the $\mathrm{cp}$ genomes were concatenated using the following 54 protein-coding genes: $\operatorname{atp} \mathrm{A}, \operatorname{atp} \mathrm{B}, \operatorname{atp} \mathrm{E}, \operatorname{atp} \mathrm{F}, \operatorname{atp} \mathrm{H}, \operatorname{atp} \mathrm{I}, \operatorname{cem} \mathrm{A}, \operatorname{chl} \mathrm{B}$, $\operatorname{chl} \mathrm{L}, \operatorname{chl} \mathrm{N}, \operatorname{clp} \mathrm{P}, \operatorname{pet} \mathrm{B}, \operatorname{pet} \mathrm{\textrm {D }}, \operatorname{pet} \mathrm{G}, \operatorname{pet} \mathrm{L}, p s a \mathrm{~A}, p s a \mathrm{~B}$, $p s a \mathrm{C}, p s a \mathrm{~J}, p s b \mathrm{~A}, p s b \mathrm{~B}, p s b \mathrm{D}, p s b \mathrm{E}, p s b \mathrm{~F}, p s b \mathrm{H}, p s b \mathrm{I}$, $p s b \mathrm{~J}, p s b \mathrm{~K}, p s b \mathrm{~L}, p s b \mathrm{M}, p s b \mathrm{~N}, p s b \mathrm{~T}, p s b \mathrm{Z}, r p l 14$, 
Table 4 Partition scheme of 54 concatenated chloroplast protein-coding genes used in this study

\begin{tabular}{|c|c|c|c|c|}
\hline \multirow[t]{2}{*}{ Subset } & \multicolumn{2}{|c|}{ Amino acid data sets } & \multicolumn{2}{|c|}{ Nucleotide data sets } \\
\hline & Best model & Partition scheme & $\begin{array}{l}\text { Best } \\
\text { model }\end{array}$ & Partition scheme \\
\hline 1 & $L G+I+G$ & rps12, ch/L, atpB, atpA & $\mathrm{GTR}+\mathrm{I}+$ & atpA, rps19, tufA, atpF, atpl, ycf12, petL \\
\hline 2 & $L G+G$ & $\operatorname{atpF}, c h / N, \operatorname{atp} E$ & $\mathrm{GTR}+\mathrm{I}+$ & $\begin{array}{l}\text { psaJ, psbZ, psbB, psaB, petD, psbD, psbK, petB, ycf3, psbH, } \\
\text { rp/16, atpB, rp/14 }\end{array}$ \\
\hline 3 & $\begin{array}{l}\mathrm{MTZOA}+\mathrm{G}+ \\
\mathrm{F}\end{array}$ & $\begin{array}{l}\text { psbM, petB, psbl, psbE, psbT, psbN, atpH, psbD, psbB, } \\
\text { psaA, psaB }\end{array}$ & $\underset{G}{G T R+I+}$ & ycf4, rps12, rp/2, atpE \\
\hline 4 & CPREV $+\mathrm{G}$ & rps19, atpl, ch/B, rp/16, rp/2, rp/5 & $\mathrm{GTR}+\mathrm{G}$ & $a t p H, p s b A$ \\
\hline 5 & CPREV $+\mathrm{G}$ & rps14, rp/20, rps9, cemA, ycf4 & $\mathrm{GTR}+\mathrm{G}$ & psbM, psbl, psaC, psbL, psbF, psbE, cemA, rp/36, rps 14 \\
\hline 6 & $J T+G+F$ & $r p s 18, r p s 8, r p / 23, r p s 3, c \mid p P$ & $\underset{G}{G T R+1+}$ & $p s b N, \operatorname{ch} / \mathrm{B}, \operatorname{ch} / \mathrm{L}, r p s 11, r p / 5, c h / N$ \\
\hline 7 & $\mathrm{MTZOA}+\mathrm{G}$ & psaJ, psbF, psbJ, psbK, psbH, petL, psbZ, petD & $\mathrm{GTR}+\mathrm{G}$ & clpP, rps7 \\
\hline 8 & LG & $\operatorname{petG}, y c f 3$ & $\mathrm{GTR}+\mathrm{G}$ & psbJ, psbT, petG \\
\hline 9 & $\mathrm{PMB}+\mathrm{G}$ & $r p / 36, p s b A, p s a C$ & $\underset{G}{G T R+1+}$ & psaA \\
\hline 10 & LG & rps11, psbL, rp/14 & $\mathrm{GTR}+\mathrm{G}$ & rps2, rps8, rps9, rp/20, rp/23, rps 18 \\
\hline 11 & $L G+G$ & rps2 & $\mathrm{GTR}+\mathrm{G}$ & rps3 \\
\hline 12 & $\mathrm{FLU}+\mathrm{G}$ & rps7 & & \\
\hline 13 & $L G 4 M+G$ & tufA & & \\
\hline 14 & MTZOA & ycf12 & & \\
\hline
\end{tabular}

rpl16, rpl2, rpl20, rpl23, rpl36, rpl5, rps11, rps12, rps14, rps18, rps19, rps2, rps3, rps7, rps8, rps9, tufA, $y c f 12, y c f 3, y c f 4$. The amino acid sequences were aligned using MAFFT 7.0 [67], and those employed in the nucleotide dataset were additionally aligned using the MUSCLE function of MEGA7 [68] with the option "align codons" [69]. Ambiguous regions were removed from each alignment using trimAl 1.2 [70] with the option gt $=1$. Evolutionary models and partitions of the datasets were determined using PartitionFinder 2 [71], and the best partitions are shown in Table 3. ML and Bayesian analyses were used for inferring phylogenies. IQ-TREE web server [72] was employed to perform ML analysis with 1000 ultrafast bootstraps [73] and $1000 \mathrm{SH}$-aLRT tests [73, 74] to examine nodal support. Bayesian analysis was conducted using MrBayesv3.2.6 [75], and the dataset was partitioned as shown in Table 4. Markov chain Monte Carlo analyses were run with four Markov chains (three heated, one cold) for 1,000,000 generations, and trees were sampled every 1000 generations. In each round of calculation, a fixed number of samples (burn-in =1000) was discarded from the beginning of the chain. Reference sequences were downloaded from GenBank. 18S rDNA sequences were aligned using MAFFT 7.0 [67], and ambiguous regions were manually edited and adjusted by eye using MEGA7 [68]. Bayesian inference (BI) of the software program MrBayes v3.2.6 [75] was used, and an evolutionary model was determined using jModelTest2 with the best model was GTR $+\mathrm{I}+\mathrm{G}$ [76]. An alignment of the $\mathrm{cp}$ genome sequences of all the species of Oedogoniales was generated using Mauve ver. 2.3.1 with the progressive mode [77]. FastANI [78] was employed to determine the ANI of all the $\mathrm{cp}$ genomes.

\section{Evolutionary analysis}

The CODEML program of PAML v4.9 [30] with the ML model (runmode $=-2$, CodonFreq $=2$ ) was used to measure the values of $\mathrm{dS}$ and $\mathrm{dN}$, the analysis was based on 54 chloroplast protein-coding genes. Comparisons of the evolutionary rates were conducted using the two-tailed Wilcoxon rank sum test. The multiple testing was corrected by applying the false discovery rate method (FDR) [79].Branch-site model was utilized to find genes that possibly underwent positive selection. The improved branch-site model ( model $=2$, Nsites $=2$ ) was used to detect signatures of positive selection on individual codons in a specific branch [80]. The three Oedocladium species and the terrestrial Oedogonium sp. (strain FACHB-3313) were set as the foreground branch. The null model assumed that no positive selection occurred on the foreground branch (fix_omega $=1$, omega $=1$ ), and the alternative model assumed that sites on the foreground branch were under positive selection (fix omega $=0$, omega $=2$ ). LRT were used to test model fit and Chi-square test was applied for examining the 
$P$ values. A correction was performed for multiple testing using an FDR criterion, and BEB method was employed to statistically identify sites under positive selection. Genes with an FDR-adjusted $P<0.05$ were considered as putatively selected.

\section{Abbreviations}

OCC clade: Oedogoniales, chaetophorales, and chaetopeltidales; IR: Inverted repeats; ML: Maximum likelihood; cpDNA: Chloroplast DNA; Oe.: Oedogonium; O.: Oedocladium; FACHB: Freshwater Algae Culture Collection at the Institute of Hydrobiology; $\mu \mathrm{m}$ : Micrometer; BEB: Bayes empirical Bayes

\section{Supplementary Information}

The online version contains supplementary material available at https://doi. org/10.1186/s12864-021-08006-1.

\section{Additional file 1: Supplementary Fig. S1. Gene map of Oe.}

dentireticulatum chloroplast genomes.

Additional file 2: Supplementary Fig. S2. Gene map of Oe. crispum chloroplast genomes.

Additional file 3: Supplementary Fig. S3. Gene map of Oe. sp. (FACHB-3311) chloroplast genomes.

Additional file 4: Supplementary Fig. S4. Gene map of Oe. capilliforme chloroplast genomes.

Additional file 5: Supplementary Fig. S5. Gene map of Oe. sp. (FACHB-3313) chloroplast genomes. Arrows show the direction of transcription. The same colour block shows the functional gene group (legend at bottom left). Transfer RNAs are represented by their one-letter amino acid code. The grey circle on the inside shows a graph of the GC content.

Additional file 6: Supplementary Fig. S6. Heat map of ANI values of the nine Oedogoniales cp genomes.

Additional file 7: Supplementary Fig. S7. Phylogenetic tree of the Oedogoniales algae based on $18 \mathrm{~S}$ rDNA sequences. Numbers at the branches represent Bayesian posterior probabilities $(\geq 0.5)$. Branch lengths are proportional to the genetic distances, which are indicated by the scale bar (Bold species are the newly included in this study).

Additional file 8: Supplementary Table S1. Insertion sites of group I introns of the nine Oedogoniaes cp genomes [81].

Additional file 9: Supplementary Table S2. Insertion sites of group ॥ introns of the nine Oedogoniaes cp genomes [81].

Additional file 10: Supplementary Table S3. Substitution rates in the chloroplast protein coding genes of Oedogoniales species.

\section{Acknowledgements}

Special thanks go to Benwen Liu and Huan Zhu for their helpful advice. The research was supported by the Wuhan Branch, Supercomputing Center, Chinese Academy of Sciences, China.

\section{Authors' contributions}

Q. Xiong: original concept, culture experiments, data analysis, writing and editing manuscript; Y. Hu, W. Lv, H. Wang: analyzed and interpreted the data. All authors revised, read, and approved the final version of the manuscript.

\section{Funding}

This work was supported by Key Research Program of Frontier Sciences, CAS (Grant No. QYZDY-SSWSMC029-6) and the National Natural Science Foundation of China (grant no. 31750001).

\section{Availability of data and materials}

All data generated and analysed during this study are included in this published article and its supplementary information files. Raw sequencing data of all species are available from the National Center for Biotechnology Information (NCBI) (https://www.ncbi.nlm.nih.gov/). Accession numbers of cpDNA: MW250871-MW250875.
MW250871: https://www.ncbi.nlm.nih.gov/nuccore/MW250871 MW250872: https://www.ncbi.nlm.nih.gov/nuccore/MW250872 MW250873: https://www.ncbi.nlm.nih.gov/nuccore/MW250873 MW250874: https://www.ncbi.nlm.nih.gov/nuccore/MW250874 MW250875: https://www.ncbi.nlm.nih.gov/nuccore/MW250875

\section{Declarations}

Ethics approval and consent to participate

Not applicable.

\section{Consent for publication}

Not applicable.

\section{Competing interests}

The authors declare that they have no competing interests.

\section{Author details}

${ }^{1}$ Institute of Hydrobiology, Chinese Academy of Sciences, Wuhan 430072, China. ${ }^{2}$ University of Chinese Academy of Sciences, Beijing 100039, China. ${ }^{3}$ Yangtze River Basin Ecological Environment Monitoring and Scientific Research Center, Yangtze River Basin Ecological Environment Supervision and Administration Bureau, Ministry of Ecological Environment, Wuhan, China. ${ }^{4}$ Department of Biology, Taiyuan Normal University, Jinzhong 030619, PR China. ${ }^{5}$ State Key Laboratory of Freshwater Ecology and Biotechnology, Institute of Hydrobiology, Chinese Academy of Sciences, Wuhan 430072, China.

Received: 22 April 2021 Accepted: 20 July 2021

Published online: 30 September 2021

\section{References}

1. Agardh CA. Synopsis Algarum Scandinaviae, adjecta dispositione universali Algarum; 1817. https://doi.org/10.5962/bhl.title.45465. Lundae

2. De Bary A. Ueber die Algengattungen Oedogonium und Bulbochaete. Frankfurt: Abhandlung Senckenberg Naturf Ges. 1854;1:29-105.

3. Stahl E. Oedocladium protonema, eine neue Oedogoniaceen-Gattung. Wiss Bot. 1891;23:339-48

4. Hirn KE. Monographie und Iconographie der Oedogoniaceen. Acta Soc Scienti Fennicae. 1900;27:1-395. https://doi.org/10.5962/bhl.title.60181.

5. Tiffany LH. North American Flora: Oedogoniales. New York: Botanical Garden; 1937.

6. Gemeinhardt K. Oedogoniales. In: L. Rabenhorst (Editor), Kryptogamen Flora XII. Ak. Verlagsgesellschaft, Leipzig; 1939.

7. Islam NAKM, Sarma P. Two new species of terrestrial Oedogonium from East Pakistan. Trans Amer Micros Soc. 1963;82(1):74-7. https://doi.org/10.23 07/3223822

8. Gauthier-Lièvre L. Oedogoniacées Africaines. Cramer, Stuttgart: Verlag von J; 1964.

9. Jao CC. Monographia Oedogoniales Sinicae. Beijing: Science Press; 1979

10. Mrozińska T. Oedogoniophyceae: Oedogoniales. In: Süßwasserflora von Mitteleuropa 14;Chlorophyta VI. Stuttgart: Gustav Fischer Verlag; 1985.

11. van Den Hoek C, Mann DG, Jahns UM. Algae: An introduction to phycology. Cambridge: Cambridge University Press; 1995.

12. Graham LE. Wilcox. Prentice Hall, Upper Saddle River, NJ: LW. Algae; 2000.

13. Liu GX, Hu ZY. Predominant occurrence of apical cell divisions in Oedogoniam pakistanense and its phylogenetic significance. Phycologia. 2004;43(6):669-71. https://doi.org/10.2216/i0031-8884-43-6-669.1.

14. Wittrock VB. Prodromus Monographiae Oedogoniearum. Nova Acta Regiae Societatis Scientiarum Upsaliensis. 1874;3:1-64.

15. Booton GC, Floyd GL, Fuerst PA. Origins and affinities of the filamentous green algal orders Chaetophorales and Oedogoniales based on 18S rRNA gene sequences. J Phycol. 1998;34(2):312-8. https://doi.org/10.1046/j.15298817.1998.340312.x

16. Buchheim MA, Michalopulos EA, Buchheim JA. Phylogeny of the Chlorophyceae with special reference to the Sphaeropleales: a study of $18 \mathrm{~S}$ and 26S rDNA data. J Phycol. 2001;37(5):819-35. https://doi.org/10.1046/j.1 529-8817.2001.00162.x

17. Krienitz L, Hegewald E, Hepperle D, Wolf M. The systematics of coccoid green algae. 18S rRNA gene sequence data versus morphology. Biologia. 2003;58:437-46 
18. Shoup S, Lewis LA. Polyphyletic origin of parallel basal bodies in swimming cells of Chlorophycean green algae (Chlorophyta). J Phycol. 2003;39(4):78996. https://doi.org/10.1046/j.1529-8817.2003.03009.x.

19. Alberghina JS, Vigna MS, Confalonieri VA. Phylogenetic position of the Oedogoniales within the green algae (Chlorophyta) and the evolution of the absolute orientation of the flagellar apparatus. Plant Syst Evol. 2006. 261(1-4):151-63. https://doi.org/10.1007/s00606-006-0449-2.

20. Mei H, Luo W, Liu GX, Hu ZY. Phylogeny of Oedogoniales (Chlorophyceae, Chlorophyta) inferred from 18S rDNA sequences with emphasis on the relationships in the genus Oedogonium based on ITS-2 sequences. Plant Syst Evol. 2007;265(3-4):179-91. https://doi.org/10.1007/s00606-007-0523-4.

21. Ravi V, Khurana JP, Tyagi AK, Khurana P. An update on chloroplast genomes. Plant Syst Evol. 2008;271(1-2):101-22. https://doi.org/10.1007/s00606-0070608-0.

22. Burke SV, Grennan CP, Duvall MR. Plastome sequences of two New World bamboos-Arundinaria gigantea and Cryptochloa strictiflora (Poaceae) —extend phylogenomic understanding of Bambusoideae. Am J Bot. 2012;99(12):1951-61. https://doi.org/10.3732/ajb.1200365.

23. Dong W, Xu C, Cheng T, Zhou S. Complete chloroplast genome of Sedum sarmentosum and chloroplast genome evolution in Saxifragales. PLoS One. 2013;8(10).

24. Huang H, Shi C, Liu Y, Mao S-Y, Gao L-Z. Thirteen camellia chloroplast genome sequences determined by high-throughput sequencing: genome structure and phylogenetic relationships. BMC Evol Biol. 2014;14(1). https:// doi.org/10.1186/1471-2148-14-151.

25. Yi D-K, Lee H-L, Sun B-Y, Chung MY, Kim K-J. The complete chloroplast DNA sequence of (Araliaceae); comparative evolutionary analyses with other three asterids. Mol Cell. 2012;33(5):497-508. https://doi.org/10.1007/s10059012-2281-6.

26. Lemieux C, Otis C, Turmel M. Chloroplast phylogenomic analysis resolves deep-level relationships within the green algal class Trebouxiophyceae. BMC Evol Biol. 2014;14(1):211. https://doi.org/10.1186/s12862-014-0211-2.

27. Zhang Z, An M, Miao J, Gu Z, Liu C, Zhong B. The Antarctic Sea ICE alga Chlamydomonas sp. ICE-L provides insights into adaptive patterns of chloroplast evolution. BMC Plant Biol. 2018;18(1). https://doi.org/10.1186/s12 870-018-1273-x

28. Brouard J-S, Otis C, Lemieux C, Turmel M. Chloroplast DNA sequence of the green alga Oedogonium cardiacum (Chlorophyceae): unique genome architecture, derived characters shared with the Chaetophorales and novel genes acquired through horizontal transfer. BMC Genomics. 2008;9(1). https://doi.org/10.1186/1471-2164-9-290.

29. Brouard J-S, Turmel M, Otis C, Lemieux C. Proliferation of group II introns in the chloroplast genome of the green alga Oedocladium carolinianum (Chlorophyceae). Peerj. 2016:4:e2627. https://doi.org/10.7717/peerj.2627.

30. Yang Z. PAML 4: phylogenetic analysis by maximum likelihood. Mol Biol Evol. 2007;24(8):1586-91. https://doi.org/10.1093/molbev/msm088.

31. Hu Y, Xing W, Song H, Zhu H, Liu G, Hu Z. Evolutionary analysis of unicellular species in Chlamydomonadales through chloroplast genome comparison with the colonial Volvocine algae. Front Microbiol. 2019;10. https://doi.org/10.3389/fmicb.2019.01351.

32. Smith DR. Mutation rates in plastid genomes. They are lower than you might think. Genome Biol Evol. 2015;7(5):1227-34. https://doi.org/10.1093/ gbe/evv069.

33. Iram S, Hayat M, Tahir M, Gul A, Abdullah Al. Chloroplast genome sequence of Artemisia scoparia: comparative analyses and screening of mutational hotspots. Plants (Basel). 2019;8:476.

34. Henriquez CL, Abdullah Al, Carlsen MM, Zuluaga A, Croat TB, McKain MR. Molecular evolution of chloroplast genomes in Monsteroideae (Araceae). Planta. 2020;251(3):72.

35. Besendahl A, Qiu YL, Lee JH, Palmer JD, Bhattacharya D. The cyanobacterial origin and vertical transmission of the plastid tRNA(Leu) group-l intron. Curr Genet. 2000;37(1):12-23. https://doi.org/10.1007/s002940050002.

36. Xiong Q, Hu Y, Liu B, Zhu H, Liu G, Hu Z. Chloroplast genomes and phylogenetic analysis of two species of Oedocladium (Oedogoniales, Chlorophyta). Eur J Phycol. 2021:1-13. https://doi.org/10.1080/09670262.202 0.1849816

37. Dussert Y, Mazet ID, Couture C, Gouzy J, Piron MC, Kuchly C, Bouchez O, Rispe C, Mestre P, Delmotte F. A high-quality grapevine downy mildew genome assembly reveals rapidly evolving and lineage-specific putative host adaptation genes. Genome Biol Evol. 2019:11(3):954-69.
38. Watanabe S, Fucikova K, Lewis LA, Lewis PO. Hiding in plain sight: Koshicola spirodelophila gen. Et sp nov (Chaetopeltidales, Chlorophyceae), a novel green alga associated with the aquatic angiosperm Spirodela polyrhiza. Am J Bot. 2016;103(5):865-75. https://doi.org/10.3732/ajb.1500481.

39. Khakhlova O, Bock R. Elimination of deleterious mutations in plastid genomes by gene conversion. Plant J. 2006;46(1):85-94. https://doi.org/1 0.1111/j.1365-313X.2006.02673.X.

40. Raubeson LA, Peery R, Chumley TW, Dziubek C, Fourcade HM, Boore JL, et al. Comparative chloroplast genomics: analyses including new sequences from the angiosperms Nuphar advena and Ranunculus macranthus. BMC Genomics. 2007:8(1):174. https://doi.org/10.1186/1471-2164-8-174.

41. Wang R-J, Cheng C-L, Chang C-C, Wu C-L, Su T-M, Chaw S-M. Dynamics and evolution of the inverted repeat-large single copy junctions in the chloroplast genomes of monocots. BMC Evol Biol. 2008;8(1). https://doi. org/10.1186/1471-2148-8-36.

42. Park I, Yang S, Kim WJ, Noh P, Lee HO, Moon BC. The complete chloroplast genomes of six ipomoea species and Indel marker development for the discrimination of authentic Pharbitidis semen (seeds of I-nil or I-purpurea). Front Plant Sci. 2018;9. https://doi.org/10.3389/fpls.2018.00965.

43. Lu Q, Ye W, Lu R, Xu W, Qiu Y. Phylogenomic and comparative analyses of complete Plastomes of Croomia and Stemona (Stemonaceae). Int J Mol Sci. 2018;19(8):2383

44. Kim KJ, Lee HL. Complete chloroplast genome sequences from Korean ginseng (Panax schinseng Nees) and comparative analysis of sequence evolution among 17 vascular plants. DNA Res. 2004;11(4):247-61. https://doi. org/10.1093/dnares/11.4.247.

45. Goulding SE, Olmstead RG, Morden CW, Wolfe KH. Ebb and flow of the chloroplast inverted repeat. Mol Gen Genet. 1996;252(1-2):195-206. https:// doi.org/10.1007/BF02173220

46. Meng X-X, Xian Y-F, Xiang L, Zhang D, Shi Y-H, Wu M-L, et al. Complete chloroplast genomes from Sanguisorba: identity and variation among four species. Molecules. 2018;23(9):2137.

47. Choi I-S, Jansen R, Ruhlman T. Lost and found. Return of the inverted repeat in the legume clade defined by its absence. Genome Biol Evol. 2019;11(4): 1321-33. https://doi.org/10.1093/gbe/evz076.

48. Pollock DD, Zwickl DJ, McGuire JA, Hillis DM. Increased taxon sampling is advantageous for phylogenetic inference. Syst Biol. 2002;51(4):664-71. https://doi.org/10.1080/10635150290102357.

49. Wang L, Wuyun T-N, Du H, Wang D, Cao D. Complete chloroplast genome sequences of Eucommia ulmoides: genome structure and evolution. Tree Genet Genomes. 2016;12(1):12

50. Ma Q, Li S, Bi C, Hao Z, Sun C, Ye N. Complete chloroplast genome sequence of a major economic species, Ziziphus jujuba (Rhamnaceae). Curr Genet. 2017;63(1):117-29. https://doi.org/10.1007/s00294-016-0612-4.

51. Fan W-B, Wu Y, Yang J, Shahzad K, Li Z-H. Comparative chloroplast genomics of Dipsacales species: insights into sequence variation, adaptive evolution, and phylogenetic relationships. Front Plant Sci. 2018;9. https://doi. org/10.3389/fpls.2018.00689.

52. Gao C, Deng Y, Wang J. The complete chloroplast genomes of Echinacanthus species (Acanthaceae): phylogenetic relationships, adaptive evolution, and screening of molecular markers. Front Plant Sci. 2019;9. https://doi.org/10.3389/fpls.2018.01989.

53. Wu Y, Liu F, Yang D-G, Li W, Zhou X-J, Pei X-Y, et al. Comparative chloroplast genomics of Gossypium species: insights into repeat sequence variations and phylogeny. Front Plant Sci. 2018;9. https://doi.org/10.3389/ fpls.2018.00376

54. Ferreira KN, Iverson TM, Maghlaoui K, Barber J, Iwata S. Architecture of the photosynthetic oxygen-evolving center. Science. 2004;303(5665):1831-8. https://doi.org/10.1126/science.1093087.

55. Gui L, Jiang S, Xie D, Yu L, Huang Y, Zhang Z, et al. Analysis of complete chloroplast genomes of curcuma and the contribution to phylogeny and adaptive evolution. Gene. 2020;732:144355. https://doi.org/10.1016/j.gene.2 020.144355

56. Moritz C, Hillis DM. Molecular systematics. Massachusetts: Sinauer Sunderland; 1996

57. Hu Y, Xing W, Song H, Liu G, Hu Z. Analysis of mitochondrial and chloroplast genomes in two volvocine algae: Eudorina elegans and Eudorina cylindrica (Volvocaceae, Chlorophyta). Eur J Phycol. 2019;54(2):193-205. https://doi.org/10.1080/09670262.2018.1539526.

58. Chen $Y$, Chen $Y$, Shi C, Huang Z, Zhang Y, Li S, et al. SOAPnuke. A MapReduce acceleration-supported software for integrated quality control 
and preprocessing of high-throughput sequencing data. Gigascience. 2017; 7(1):1-6.

59. Bankevich A, Nurk S, Antipov D, Gurevich AA, Dvorkin M, Kulikov AS, et al. SPAdes: a new genome assembly algorithm and its applications to singlecell sequencing. J Comput Biol. 2012;19(5):455-77. https://doi.org/10.1089/ cmb.2012.0021.

60. Li H. Aligning sequence reads, clone sequences and assembly contigs with BWA-MEM. arXiv. 2013;1303.3997:1-3.

61. Tillich M, Lehwark P, Pellizzer T, Ulbricht-Jones ES, Fischer A, Bock R, et al. GeSeq - versatile and accurate annotation of organelle genomes. Nucleic Acids Res. 2017;45(W1):W6-W11. https://doi.org/10.1093/nar/gkx391.

62. Lowe TM, Chan PP. tRNAscan-SE on-line: integrating search and context for analysis of transfer RNA genes. Nucleic Acids Res. 2016;44(W1):W54-7. https://doi.org/10.1093/nar/gkw413.

63. Michel F, Umesono K, Ozeki H. Comparative and functional anatomy of group II catalytic introns--a review. Gene. 1989;82(1):5-30. https://doi.org/1 0.1016/0378-1119(89)90026-7.

64. Michel F, Westhof E. Modelling of the three-dimensional architecture of group I catalytic introns based on comparative sequence analysis. J Mol Biol. 1990;216(3):585-610. https://doi.org/10.1016/0022-2836(90)90386-Z.

65. Lang BF, Laforest M-J, Burger G. Mitochondrial introns: a critical view. Trends Genet. 2007;23(3):119-25. https://doi.org/10.1016/j.tig.2007.01.006.

66. Lohse M, Drechsel O, Bock R. OrganellarGenomeDRAW (OGDRAW): a tool for the easy generation of high-quality custom graphical maps of plastid and mitochondrial genomes. Curr Genet. 2007;52(5-6):267-74. https://doi. org/10.1007/s00294-007-0161-y.

67. Katoh K, Standley DM. MAFFT multiple sequence alignment software version 7: improvements in performance and usability. Mol Biol Evol. 2013; 30(4):772-80. https://doi.org/10.1093/molbev/mst010.

68. Kumar S, Stecher G, Tamura K. MEGA7: molecular evolutionary genetics analysis version 7.0 for bigger datasets. Mol. Biol. Evol. 2016;33(7):1870-4.

69. Edgar RC. MUSCLE: multiple sequence alignment with high accuracy and high throughput. Nucleic Acids Res. 2004;32(5):1792-7. https://doi.org/10.1 093/nar/gkh340

70. Capella-Gutierrez S, Silla-Martinez JM, Gabaldon T. trimAl: a tool for automated alignment trimming in large-scale phylogenetic analyses. Bioinformatics. 2009;25(15):1972-3. https://doi.org/10.1093/bioinformatics/ btp348.

71. Lanfear R, Frandsen PB, Wright AM, Senfeld T, Calcott B. PartitionFinder 2: new methods for selecting partitioned models of evolution for molecular and morphological phylogenetic analyses. Mol Biol Evol. 2017;34(3):772-3. https://doi.org/10.1093/molbev/msw260.

72. Trifinopoulos J, Lam-Tung N, von Haeseler A, Minh BQ. W-IQ-TREE: a fast online phylogenetic tool for maximum likelihood analysis. Nucleic Acids Res. 2016;44(W1):W232-5. https://doi.org/10.1093/nar/gkw256.

73. Bui Quang M. Minh Anh Thi N, von Haeseler a. ultrafast approximation for phylogenetic bootstrap. Mol. Biol. Evol. 2013;30(5):1188-95.

74. Guindon S, Dufayard J-F, Lefort V, Anisimova M, Hordijk W, Gascuel O. New algorithms and methods to estimate maximum-likelihood phylogenies: assessing the performance of PhyML 3.0. Syst. Biol. 2010;59(3):307-21.

75. Ronquist F, Teslenko M, van der Mark P, Ayres DL, Darling A, Hohna S, et al. MrBayes 3.2: efficient Bayesian phylogenetic inference and model choice across a large model space. Syst. Biol. 2012;61(3):539-42.

76. Darriba D, Taboada GL, Doallo R, Posada D. jModelTest 2: more models, new heuristics and parallel computing. Nat methods. 2012;9:772.

77. Darling AE, Mau B, Perna NT. progressiveMauve: multiple genome alignment with gene gain, loss and rearrangement. PLoS One. 2010;5(6): e11147.

78. Jain C, Rodriguez-R LM, Phillippy AM, Konstantinidis KT, Aluru S. High throughput ANI analysis of 90K prokaryotic genomes reveals clear species boundaries. Nat Commun. 2018;9(1):5114. https://doi.org/10.1038/s41467-01 8-07641-9.

79. Benjamini $Y$, Hochberg $Y$. Controlling the false discovery rate: a practical and powerful approach to multiple testing. J R stat Soc Ser B Stat. 1995;57: 289-300.

80. Zhang JZ, Nielsen R, Yang ZH. Evaluation of an improved branch-site likelihood method for detecting positive selection at the molecular level. Mol Biol Evol. 2005;22(12):2472-9. https://doi.org/10.1093/molbev/msi237.

81. Lemieux C, Otis C, Turmel M. Ancestral chloroplast genome in Mesostigma viride reveals an early branch of green plant evolution. Nature. 2000;Suppl 403:649-52.

\section{Publisher's Note}

Springer Nature remains neutral with regard to jurisdictional claims in published maps and institutional affiliations.

\section{Ready to submit your research? Choose BMC and benefit from:}

- fast, convenient online submission

- thorough peer review by experienced researchers in your field

- rapid publication on acceptance

- support for research data, including large and complex data types

- gold Open Access which fosters wider collaboration and increased citations

- maximum visibility for your research: over $100 \mathrm{M}$ website views per year

At BMC, research is always in progress.

Learn more biomedcentral.com/submissions 